Portland State University

PDXScholar

5-15-1985

\title{
The Effect of Women's Labor Force Participation on Marital Instability
}

Isik Akin Aytac

Portland State University

Follow this and additional works at: https://pdxscholar.library.pdx.edu/open_access_etds

Part of the Family, Life Course, and Society Commons, and the Work, Economy and Organizations Commons

Let us know how access to this document benefits you.

\section{Recommended Citation}

Aytac, Isik Akin, "The Effect of Women's Labor Force Participation on Marital Instability" (1985).

Dissertations and Theses. Paper 3428.

https://doi.org/10.15760/etd.5307

This Thesis is brought to you for free and open access. It has been accepted for inclusion in Dissertations and Theses by an authorized administrator of PDXScholar. Please contact us if we can make this document more accessible: pdxscholar@pdx.edu. 
AN ABSTRACT OF THE THESIS OF Isik Akin Aytac for the Master of Science in Sociology presented May 10, 1985.

Title: The Effect of Women's Labor Force Participation on Marital Instability.

APPROVED BY MEMBERS OF THE THESIS COMMITTEE:

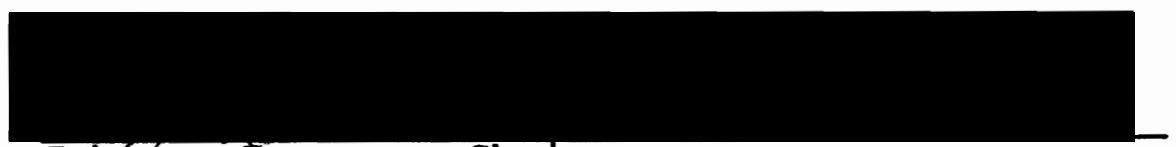

Joharna Brenner, Chairperson

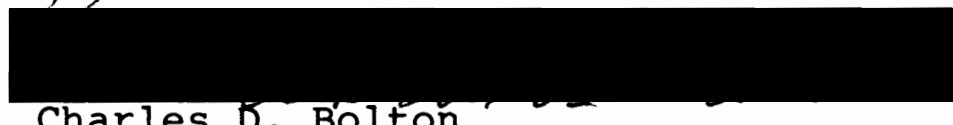

Charles B. Bolton

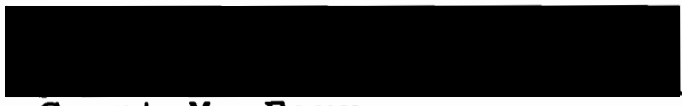

Grant M. Farr

This thesis examines the effect of women's labor force participation on marital instability. It is hypothesized that women's income-earning affects marriage in two ways: 1) the "independence effect" facilitates divorce by enabling women to be self-supporting; 2) the "parallel marriage effect" improves marital satisfaction and the quality of the marital relationship because women with higher incomes generally have more power in marriage. The "independence effect" is measured by whether or not women's income is sufficient, defined as income above the poverty line for the appropriate family size as established by the U.S. Bureau of 
Labor Statistics. "Parallel marriage" is measured by the wife-husband income ratio. Both women's own income level and wife-husband income ratio are taken two years prior to her divorce.

It is hypothesized that women with sufficient income will have a higher divorce rate than women with insufficient income. It is also hypothesized that women with incomes closer to their husband's incomes will have "parallel" marriages and lower rate of divorce. In order to determine the net effects of sufficient income and income ratio on divorce, other factors that may affect divorce rates are controlled for--family income, education, presence of preschool age or school-age children, and woman's age.

This study uses data from the National Longitudinal Survey of Labor Market Experience (NLS) designed by the Ohio State University and the U.S. Bureau of the Census. NLS respondents were selected by a multi-stage probability sample located in 235 sample areas. These 235 sample areas included 485 counties and independent cities representing every state and the District of Columbia. This research analyzes one of the cohorts of the NLS survey--older women 34-48--who were married in 1969 and 1971 and either remained married or divorced by 1972 .

The results support the hypothesis of an "independence" effect--as women with sufficient income were three times more likely to divorce than women without sufficient incomes. The "parallel" marriage effect was not confirmed. 
The divorce rate was higher among couples with closer incomes, and lower among couples with a higher income gap. 
THE EFFECT OF WOMEN'S LABOR FORCE PARTICIPATION ON MARITAL INSTABIIITY

by

ISIK AKIN AYTAC

A thesis submitted in partial fulfillment of the requirements for the degree of

MASTER OF SCIENCE

in

SOCIOLOGY

Portland State University

1985 


\section{TO THE OFFICE OF GRADUATE STUDIES AND RESEARCH:}

The members of the Committee approve the thesis of Isik Akin Aytac presented May 15, 1985.

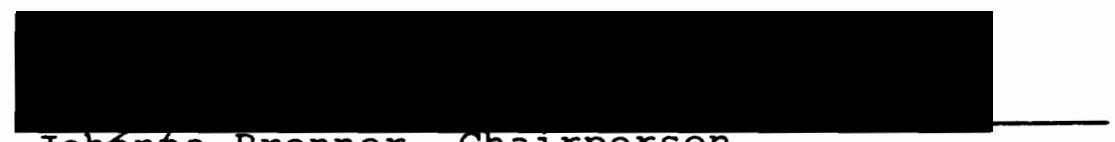

Johanła Brenner, Chairperson

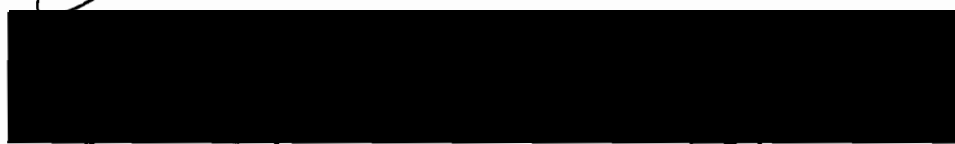

Chárles D. Bolton

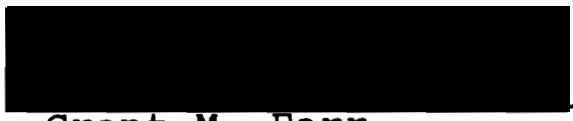

Grant M. Farr

APPROVED :

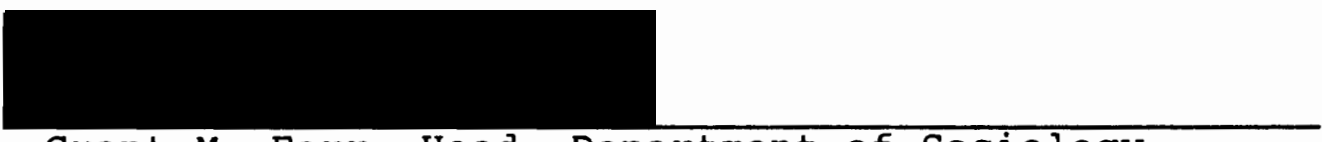

Grant M. Farr, Head, Department of Sociology

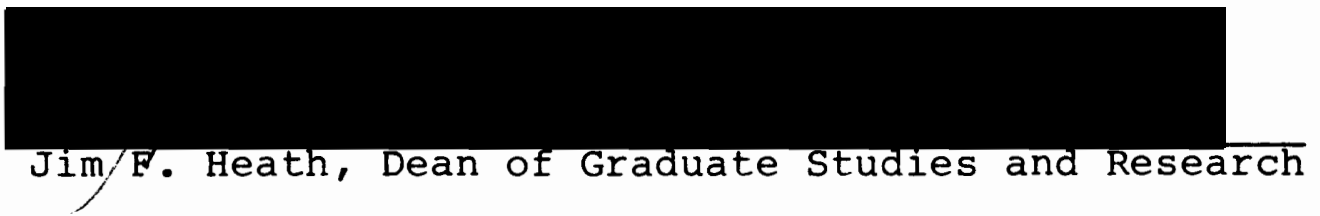




\section{TABLE OF CONTENTS}

LIST OF TABLES • • • • • • • • • • • • • • • • • • IV CHAPTER

I REVIEW OF LITERATURE AND HYPOTHESES • • • • • • 1

I I METHODOLOGY $\quad$ • • • • • • • • • • • • • • • •

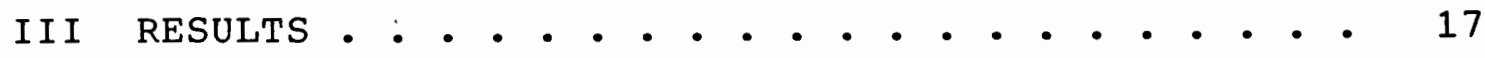

IV CONCLUSIONS • • • • • • • • • • • • • • • • 25

BIBLIOGRAPHY • • • • • • • • • • • • • • • • • 27 


\section{LIST OF TABLES}

TABLE

PAGE

I Poverty Levels for Non-farm Families, 1970 • • 14

I Percent Distribution of Marital Status by Year . 16

I I Mean Income in 1970 of Self, Husband and

Family, women Married in 1971, by Marital

Status, 1972 . . . . . . . . . . . . . 18

IV Pearson Correlation Coefficients . • • • • • • 19

V Multiple Classification Analysis with

Divorce the Dependent Variable; Women's Income,

Income Ratio the Independent Variables; and

FAMINC, EDUC, PSA, SA, AGE the Control

Variables 


\section{CHAPTER 1}

While divorce rates have fluctuated during the 20 th century, since 1950 the divorce rate has risen continuously. Since women's labor force participation grew rapidly in the same period, it is often assumed that women's employment is responsible for increasing marital instability. One explanation is that working women do not have enough time to adequately fulfill their roles as wife and mother; husbands are dissatisfied, so divorce occurs.

Traditionally, women have had all the responsibility for household chores and childcare. Full time homemakers work on average 55 hours per week, more than the average time spent in full-time employment. It is not surprising that employed women spend much less time on housework and childcare--26 hours per week (Vanek, 1974). This decline is not the result of more help from spouses. Many studies show that the husbands of employed women are not significantly more likely than husbands of homemakers to share housework and childcare (Moore, Sawhill, 1978). It does seem that when women start working outside the house, they have less time for housework and childcare.

A different hypothesis is that when women work they gain economic independence, making it easier for them to end 
an unsatisfactory marriage. As housewives, married women have been economically dependent on their husbands. This condition has changed as women gained more opportunities for paid work. In 1940 , only 158 of married women were working; by 1960,378 and by 1980,558 were in the labor force (U.S. Bureau of the Census, 1980). As a result, married women now have their own income.

To better understand the relationship of divorce to women's increased labor force participation, we need to understand why and how marriages form. Men and women in marriage almost always have a hidden economic contract. Men go out to work and bring home the income, women stay home, take care of the children and household chores. Because it is unwaged, the work that women do at home is not valued (Benston 1969, Zaretsky 1976). However, if the services a wife performs had to be purchased on the market, they would cost a great deal. When men and women come together to form a marriage, they find themselves in economicallydefined, structured roles, with the women being the economically dependent one. Therefore, Women's Labor Force Participation (WLFP) does in fact mean quite a significant change in women's lives and marital life.

While a focus on economic variables apparently ignores the complexity of the factors contributing to marital stability/disruption, recent theoretical work and research demonstrate the strong link between individuals' economic 
position and many other aspects of marital relationships (Moore, Sawhill, 1978).

A number of studies have emphasized the relationship of marital stability/instability to family income, husband's income, and wife's income. For example, although work on the black family assumed that cultural differences were primarily responsible for the higher rate of marital breakup among blacks compared to whites, recent research has demonstrated the importance of economic differences. Duncan and Morgan (1975) found that, once family income is controlled for, the black divorce/separation rate is 68 lower than the white rate. This finding suggests that it is the economic characteristics of black families--for example, the stress caused by poverty--that leads to their higher overall level of marital instability. Black husband's income has a significant impact on marital disruption (Robert Hampton 1979). Other studies have demonstrated for both blacks and whites that the higher the husband's income, the more stable the marriage, the lower the husband's income, the higher the marital instability. (Moynihan 1967; Norton and Glick 1976). In an income maintenance experiment among poor families, Groeneveld, Tuma, and Hannan found higher rates of marital dissolution among the experimental families, particularly those with non-wage earning wives. They concluded that the wives increased access to income contributed to the higher divorce rate in this group. 
Given the relationship of economic factors such as husband's income and family income to marital status, and considering that divorce rates and married women's labor force participation rates have both rapidly increased since World War II, it seems reasonable to consider the relation of the higher divorce rates to the rise in married women's labor force participation. Moore and Sawhill (1978) show that married women with income are more likely to get divorced than wives with no income.

Yet, despite this supporting data, the divorce rate is only 48 higher among working women's families compared to non-working women's families (Amsden 1980). Why are these findings so contradictory? On the one hand, the data show an increase in labor force participation of married women and an increase in divorce rate. On the other hand, the divorce rate is not very different among working married women and housewives. It is my hypothesis that WLFP does affect divorce as a result of women's economic independence. But the key point is that WLFP does not necessarily mean women's economic independence.

Women earn on average $60 \%$ of what men earn (Rothman, 1978) . 348 of all working women are segregated into lowpaid clerical service jobs. In addition, 258 of all working women are in the professional technical occupations (Blau, 1978). Half of the professional women are in traditionally female jobs, such as librarian, registered nurse, preschool or secondary teacher, and social worker (Grimm, 1978). 
Moreover, because many wives shape their labor force participation around their family responsibilities, they work part-time or in lower paid jobs that allow them to more easily combine paid and unpaid work. On average, full-time working wives account for 388 , while part-time working wives account for $25 \%$ of family income. Therefore, the proper comparison here is not wage-earning versus non-wage earning wives but between wives whose wage work earns sufficient income so that they might support themselves and wives who do not--either because they earn too little or because they do not earn at all. In short, more carefully defining the dimension of economic independence for women (i.e., sufficient incomel, should reveal a more clear relationship between WLFP and divorce.

Besides facilitating divorce (the "independence" effect), women's labor force participation, in some cases, may actually facilitate marital stability. Women's labor force participation appears to equalize family power relations (Moore, Sawhill, 1978), potentially increasing women's level of marital satisfaction and thus tending to lower rather than raise the rate of divorce.

The impact of economic factors on power relations within marriage has sometimes been understated in the literature. Often marital power inequalities are understood to be gender-determined: the husband holds greater power by virtue of his culturally-defined and socially-enforced role 
as instrumental leader, legitimate authority, etc. Missing in this interpretation is the fact that the husband also is the economically powerful person. Thus, income, which seems to have significance primarily in the public realm, in fact, affects the most private spheres and intimate relationships. Blumstein and Schwartz (1983) found that among couples where the husband is the breadwinner and the wife stays at home, decisions are made by the husband. Wives with incomes have greater autonomy, and the higher their income the more they participate in the decision-making process. Moreover, because Blumstein and Schwartz compared heterosexual and gay couples, their research demonstrates the importance of income inequality in the maintenance of traditional marital roles. If gender ideology were primarily responsible for the inequalities of power in husband-wife relationships, we would see power more equally distributed in gay couples. Yet, the Blumstein and Schwartz study shows that the partner with the higher income also has more power in gay households.

Among couples with relatively equal incomes, wives not only participate more equally in decision-making, but husbands participate more equally in domestic chores. Sharing housework and childcare is more common among couples with relatively equal incomes (Huber, Spitze 1983). It appears, then, that working women are more likely to establish "parallel marriages," i.e., marriages in which couples share decision making and family responsibilities. Since such 
marriages might be more satisfying to women, it would appear that women's labor force participation might also work to increase marital stability by increasing the marital satisfaction of wives. 1 on the other hand, it can also be argued that at least some men are threatened by their wife's working especially if this additional income allows or encourages her to make new demands or to reject or wish to revise her traditional role. This, of course, would tend to increase the positive association of divorce with women's labor force participation. However, Ross, Mirowsky, and Huber (1983) found that the depression level among both husbands and wives is lowest among "parallel" marriages. Thus, it seems that income equality between spouses is more likely to increase marital satisfaction for both men and women than to increase husbands' dissatisfaction.

It is hypothesized that the higher the husband-wife income ratio, the more equally distributed power and decision-making are, and thus the lower the divorce rate. And, the lower the husband-wife income ratio, that is, the more gap between their incomes, the less equal the relationship and the higher the divorce rate.

1 There are many different reasons for divorce. This study investigates how the economic factors in women's lives might relate to divorce, regardless of who initiates the divorce. 
The "independence" effect and "parallel" marriage may act in the same or in counterposed directions in relation to marital instability. For example when wife-husband income ratios are high, i.e., closer, there is a more parallel-type marriage; therefore we might expect lower divorce rates. But, on the other hand, it might be that those women who have more parallel marriages have higher incomes, and so they also have the economic independence which will tend to increase the likelihood of divorce. Similarly, some studies find that there is greater marital stability where the ratio of the wife's wage relative to her husband's is low. This would seem to indicate that parallel marriages are not more satisfying to the partners than marriages with larger inequalities. However, it may be that in marriages where the wife's income is low compared to her husband's income wives generally do not earn income sufficient to be self-supporting. In that case, it may be that the negative effect of unequal power relations on the wife's marital satisfaction is counter-balanced by her economic dependence. On the other hand, in the more infrequent instances where women have sufficient incomes but are married to men with significantly more income-earning power, both affects--marital power relations and women's economic independence are operating in the same direction--toward divorce. The following two by two table illustrates the line of argument. 
" pARALIEL" marRIAGE

(Wife-Husband Income Ratio)

INDEPENDENCE

EFPECT

(Wife's Income)

\begin{tabular}{|l|lc|}
\hline $\begin{array}{l}\text { Sufficient Income } \\
\text { High Gap }\end{array}$ & $\begin{array}{l}\text { Sufficient } \\
\text { Low Gap }\end{array}$ & \multicolumn{2}{c|}{ Income } \\
\hline $\begin{array}{l}\text { Insufficient Income } \\
\text { High Gap }\end{array}$ & $\begin{array}{l}\text { Insufficient } \\
\text { Low Gap }\end{array}$ & $\begin{array}{c}4 \\
\text { Lowe }\end{array}$ \\
\hline
\end{tabular}

Cell 1: Woman's income is sufficient to live by herself. Her income is less than her husband's, which means less power in the relationship. She is likely to be dissatisfied, and she can afford to divorce.

Cell 2: More equal relationship, therefore, less likelihood of divorce. But the woman has sufficient income, so she can get divorced.

Cell 3: A less equal relationship, so a woman would want to get divorced. But her income is not sufficient, so she cannot get divorced.

Cell 4: Woman's income is equal to or higher than her husband's which means the possibility of an equal relationship is greater, therefore, she would not want to get divorced. In addition, her income is not sufficient.

In cells 1 and 4 , independence effect and income ratio are working in the same direction. So we might expect to find the highest divorce rates in cell 1, and the lowest divorce rates in cell 4. In cells 2 and 3 , since the two effects operate in different directions, we would expect divorce rates to fall between the highest and lowest rates. With cell 2 and 3 the two forces are acting separately within the cell. In cell 2 , the power relation is a negative force for divorce, the partners have a more equal relation- 
ship, while the woman's income sufficiency is a positive force for divorce. In cell 3 , the partners have a less equal marriage because the woman's income is less than her husband's, so there is a positive force for divorce; but the woman's income is not sufficient for her to be independent from him, so there is a negative force for divorce. 


\section{CHAPTER II}

\section{METHODOLOGY}

The data for the analysis of marital instability in relation to economic independence and parallel marriage is taken from the National Longitudinal Survey of Labor Market Experience (NLS) designed by the Ohio state University and the U.S. Bureau of the Census. The NLS survey included biennial interviews with 5000 women, 30-44 years old beginning in 1968. These women form the basis of the present study. NLS data is well suited for this research due to its longitudinal character 1 and detailed information on labor force participation, which allowed examination of marital instability in relation to economic resources for individual women throughout the years.

\section{Sampling Procedure}

Sampling procedure consisted of a multi-stage probability sample located in 235 sample areas. Initially, all the nation's counties and independent cities were grouped into 1900 primary sampling units (PSU). To represent the

${ }^{1}$ NLS data are only available up until 1975 at portland state. Therefore this research will cover the period from 1968 to 1975 . 
civilian, non-institutional population from these 1900 PSU's, two hundred thirty-five sample areas were selected consisting of one or more relatively homogeneous PSU's according to socioeconomic characteristics. These 235 sample areas included 485 counties and independent cities representing every state and the District of Columbia.

In order to provide better statistical analysis for comparisons of blacks and whites, a three to four times higher sampling ratio for blacks was used. Each cohort initially had a 5000 sample, with approximately 3500 white and 1500 black females.

Completion rates at the end of the ten year survey were very good. In 1977, 788 of older women and in 1978, 768 of young women were interviewed.

\section{Variables}

The dependent variable, marital status, was obtained each survey year, with categories of:

1. Married spouse present.

2. Married spouse absent.

3. Widowed.

4. Divorced.

5. Separated.

6. Never married.

In this research, categories one and two were combined as the "married" group, and four and five were combined as 
the "divorced" group. By grouping into two categories, marital status variable is treated as a dichotomous variable with divorce, one, and married, zero.

Independence Effect is an independent variable measured by the woman's full-year income two years prior to her divorce. "Sufficient" income will be defined as income above the poverty level for the appropriate family size $(1,2,3,4,5)$ established by the U.S. Bureau of Labor statistics (see Table I).

Parallel Marriage Effect is also an independent variable which will be measured by the wife-husband income ratio, (in five levels: 0-208, 21-408, 41-608, 61-808, 818 or higher) two years prior to her divorce.

Family Income is used as a control variable, as divorce varies among different family income levels. Previous studies reveal that divorce is higher for lower family income levels, and lower in higher family income levels.

Age of Children is used as a control variable since age of children may effect the decision for divorce. Women with pre-school age children might find it hard to provide daycare or babysitting and, thus, postpone the decision for divorce. On the other hand, birth of a child may also precipitate divorce by disrupting the wife/husband relationship.

Women with school age children might find it easier to divorce, as they no longer have to find and pay for daycare or babysitting. 
TABLE I

POVERTY LEVELS FOR NON-FARM FAMILIES, 1970*

\begin{tabular}{|lr|}
\hline Size & $\begin{array}{c}\text { Poverty } \\
\text { Level }\end{array}$ \\
\hline 1 person & $\$ 2010$ \\
2 persons & $\$ 2604$ \\
3 persons & $\$ 3099$ \\
4 persons & $\$ 3968$ \\
5 persons & $\$ 4680$ \\
\hline
\end{tabular}

ttaken from Statistical Abstract of U.S.A. 1984, p. 447.

Education is used as a control variable, as divorce rate may vary for different education levels.

Age of woman is used as a control variable, as previous studies show that divorce is higher at earlier ages and relatively less in older groups.

During the course of the NLS survey from 1968 to 1975 , two to three percent of the married women in the older women cohort were divorced or separated between each of the survey year* (see Table II). These women, and their counterparts

*The NLS did not survey each cohort with the same questions each year. The older women group were asked their marital status in 1968, 1969, 1971, 1972, 1974. Both divorced and separated women are included in the "divorced" category. 
TABLE II

\section{PERCENT DISTRIBUTION OF MARITAL STATUS BY YEAR}

\begin{tabular}{|lllll|}
\hline \multicolumn{5}{c}{ MARITAL STATUS } \\
& 1969 & 1971 & 1972 & 1974 \\
\hline Married & $\begin{array}{l}8.48 \\
(3690)\end{array}$ & $\begin{array}{l}85.28 \\
(3482)\end{array}$ & $\begin{array}{l}85.08 \\
(3403)\end{array}$ & $\begin{array}{l}84.08 \\
(3220)\end{array}$ \\
$\begin{array}{lllll}\text { Divorced } \\
\text { a year before }\end{array}$ & $\begin{array}{l}\text { (96) } \\
\text { Remarried }\end{array}$ & $\begin{array}{l}2.7 \\
(110)\end{array}$ & $\begin{array}{l}1.8 \\
(73)\end{array}$ & $\begin{array}{l}2.4 \\
(93)\end{array}$ \\
Divorced & 1.2 & 1.3 & 0.8 & 1.7 \\
& 10.2 & 10.8 & 12.3 & 11.9 \\
\hline Total & $(436)$ & $(441)$ & $(494)$ & $(458)$ \\
\hline Total N & 1008 & 1008 & 1008 & 1008 \\
\hline
\end{tabular}

who remained married, comprised the sample for this study. In order to test the hypotheses, it was necessary to obtain information on respondent's income, husband's income and family income for both those married women who divorced and those married women who stayed married between each of the survey years. Unfortunately, income questions and marital status questions were not asked consistently over the years. Complete information on income and marital status was available for only a small part of our potential sample: those 
women who were married in 1971 and either remained married or were divorced by 1972 .

In order to eliminate as much as possible factors other than the economic variables which are the focus of this study, only women who had been married for several years, from 1969-1971, were included. ${ }^{2}$ of these women, 1.58 were divorced by 1972 .

Information on women's own income, their husband's income, and family income, was obtained for 1970. This seemed appropriate since it is likely that there is usually some time lag between the initiation and implementation of the decision to divorce or separate.

${ }^{2}$ Divorce rate in first few years may reflect basic incompatibility rather than the economic factors. 


\section{CHAPTER III}

\section{RESULTS}

There is a significant difference between the mean income of the women who divorced and the women who remained married, $\$ 4,031$ and $\$ 3,092$ respectively, indicating that married women with higher incomes have higher divorce rates. Husband's income is lower for the divorced group than for the married group $(\$ 5,909$ and $\$ 7,966$ respectively), consistent with previous findings of a higher divorce rate, the lower the husband's income. Similar results were found for the mean family income--the divorced group having a significantly lower mean family income $(\$ 9,912)$ compared to the married group $(\$ 10,457)$. (See Table III)

There is a positive and significant relationship between divorce and women's sufficient income ("independence" effect) and husband-wife income ratio ("parallel" marriage effect) (Table IV). However, these independent variables are also highly correlated with other factors known to affect divorce--family income, education, age, presence of pre-school or school age children. Multiple classification analysis (MCA) has been used to control for these variables and to identify only the net impacts of wife's income and the husband-wife income ratio on divorce. Since MCA 


\section{MEAN INCOME IN 1970 OF SELF, HUSBAND \\ AND FAMILY, WOMEN MARRIED IN 1971 \\ BY MARITAL STATUS, 1972}

$\begin{array}{lll}\text { Own } & \text { Husband's } & \text { Family } \\ \text { Income } & \text { Income } & \text { Income } \\ 1970 & 1970 & 1970\end{array}$

\begin{tabular}{|c|c|c|c|}
\hline Married 1972 & $\begin{array}{l}\$ 3,092 \star \star \star \\
(3243)\end{array}$ & $\begin{array}{l}7,966 * \text { * } \\
(3077)\end{array}$ & $\begin{array}{l}10,457 \text { * } \\
(2339)\end{array}$ \\
\hline Divorced 1972 & $\begin{array}{l}\$ 4,031 \star \star \star \\
\quad(64)\end{array}$ & $\begin{array}{c}5,909 \star \star \\
(62)\end{array}$ & $\begin{array}{c}9,192^{\star} \\
(48)\end{array}$ \\
\hline
\end{tabular}

*significance, $p=.10$

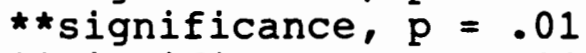

$\star \star \star$ significance, $p=.001$ 


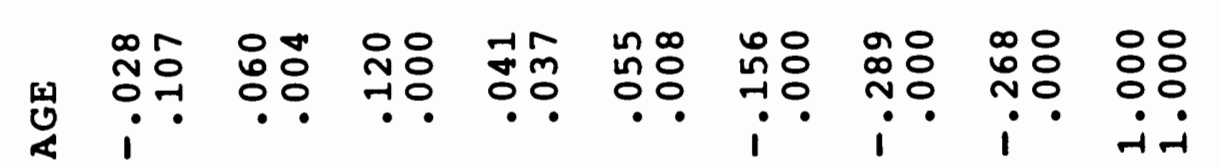

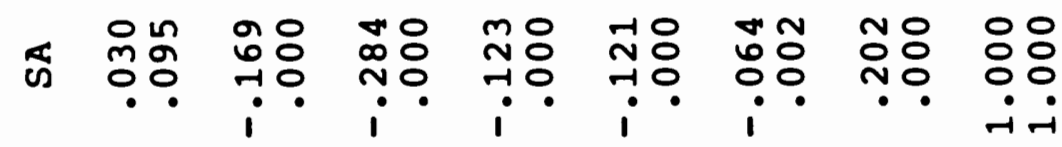

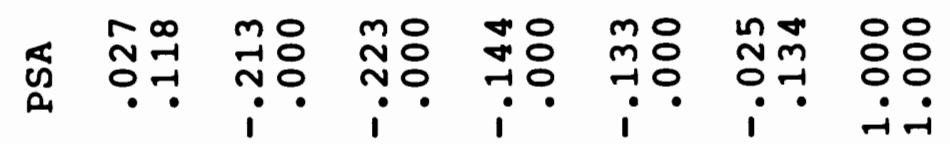

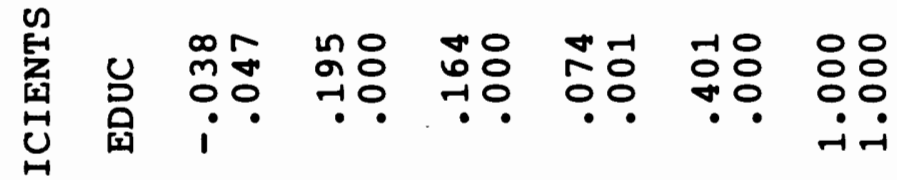

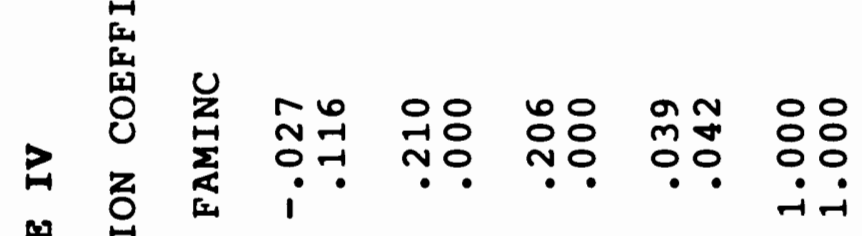

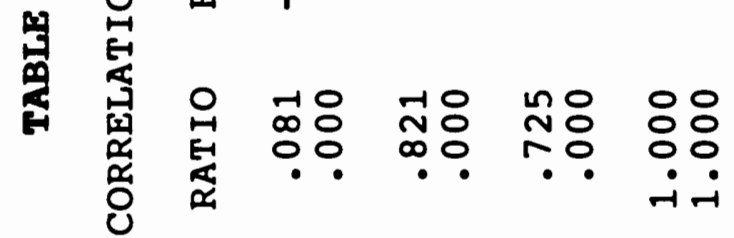

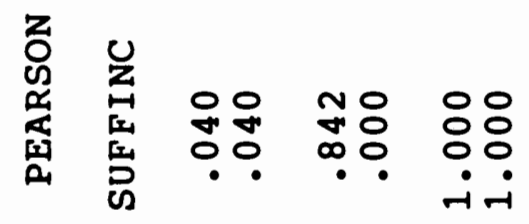

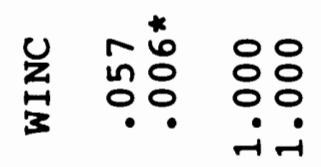

$$
\begin{aligned}
& \begin{array}{ll}
0 & 0 \\
0 & 0 \\
0 & 0 \\
\text { A } & 0
\end{array}
\end{aligned}
$$

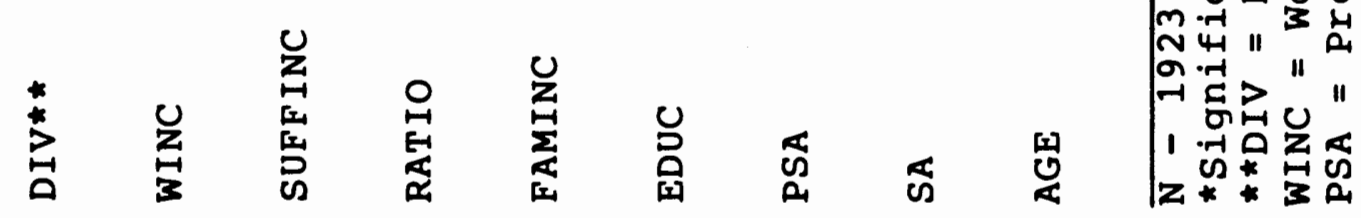


provided more information about the distribution of the divorce rate within the different levels of the two independent variables, it seemed preferable to multiple regression analysis for purposes of this study.

Women with "sufficient" incomes had a higher divorce rate, (38) than women with "insufficient" income (18). On the basis of an $F$ test this difference is significant at $p=$ .02 level. In addition, as women with insufficient income approach sufficiency, i.e., as their income rises, their rate of divorce increases markedly. Divorce rates in the "insufficient" group are low at all income levels up to $\$ 3,000$ where divorce jumps to 48 and then to 198 in the highest income group. (column III, Table V). On the other hand, among women with sufficient income, the divorce rate between income groups shows no particular pattern. Taken together, these results indicate that income-earning affects a woman's decision to divorce insofar as that income allows her to support herself and her children if she has any. Once this capacity for self support is achieved, income is much less determinative of the decision to divorce.

This result demonstrates the importance of distinguishing between various categories of working wives in assessing the impact of women's labor force participation on marital stability. Income-earning in itself does not increase the propensity for divorce. The overall higher divorce rate among women with sufficient income, the higher divorce rate around the sufficiency cut-off income level, 
and the lack of difference in rates once that level is passed, are highly supportive of the hypothesized "independence effect"

A second hypothesis of this research was that the greater the income equality between husband and wife, the lower the divorce rate. On the basis of previous studies, it was assumed that couples with relatively equal incomes would have more "parallel" and thus more satisfying marriages and therefore lower divorce rates. The results do not support this hypothesis.

The effect of a relatively equal husband-wife income ratio among married women with both "insufficient" and "sufficient" incomes is to raise the rate of divorce. Within both groups, women who earned significantly less than their husbands (high gap) were much less likely to divorce than were women whose incomes were closer to their husbands' income (low gap). Thus, among married women with sufficient incomes, 28 of wives who earned between none and 808 of their husbands' income were divorced compared to 68 of wives who earned 818 or more of what their husbands earned. Similar results were found for the women with "insufficient" incomes: the divorce rate was 18 for high gap marriages, 48 for marriages where incomes were relatively equal. This result apparently contradicts previous research which indicates that husband-wife income equality tends to produce more "parallel" marriages and that both husbands and wives 
are happier in parallel marriages. (Huber, Spitze 1983).

One possible explanation of these differing results may be that marriages in which women have incomes close to their husband's income are both more unstable and more satisfying. They are more likely to end in marital break-up-but those that do not break up will be "parallel" marriages, more satisfying than other marriages. In marriages where women make almost equal economic contributions to family support, wives may be less willing to accept the traditional roles which are generally legitimated by the husband's "breadwinner" status. In this situation, wives may feel they have more rights to equality than in a marriage where husband's income provides the primary economic support. However, husbands may be unwilling to adapt to the change wives demand. In this case, closer husband-wife income ratios would not lead to sharing and thus parallel marriages, but to marital dissolution. This would be true even in those cases where women did not earn "sufficient" incomes--for while the wife might be willing to live with the ensuing conflict, the decision to divorce is not hers alone ${ }^{1}$. From the same reasoning, marriages in which women

$1_{\text {Another }}$ interpretation of the high divorce rate in this group is that the group is composed almost entirely of poor families. Families where women have low incomes which all equal to or greater than their husbands are almost certain to be poor. This does seem to be the case. Mean family income in this group is $\$ 5,885$ while the family incomes for the other groups ranged from $\$ 8,777-\$ 11,612$. 
earn "sufficient incomes" as well as incomes close to their husband's income, would be the most divorce prone as well as potentially the most parallel.

Actual "parallel" marriages appear to be the least common form of marriage. Generally, husbands resist sharing domestic work and childcare even when their wives work. Therefore, where women can be self-supporting and where their claim to change in traditional roles appears legitimate, women may be the most demanding, and therefore their husbands may be the most dissatisfied, so both husband and wife may be likely to leave the marriage. The highest divorce rate $(68)$ is indeed found among such women in the "sufficient" group who earn at least 808 of what their husbands earn. Unfortunately, since the NLS survey provides no information on who initiated divorce, this line of explanation could not be pursued in this study. 
MULTIPLE CLASSIFICATION ANALYSIS WITH DIVORCE THE DEPENDENT VARIABIE; WOMEN'S INCONE, INCONE RATIO, THE INDEPENDENT VARIABLES; AND FAMINC, EDUC, PSA, SA, AGE THE CONTROL VARIABIES.

PERCENT DIVORCED 1972 AMONG WOMEN MARRIED

1969-1971, WITH SUFFICIENT OR INSUFFICIENT INCONE, 1970.

I

II

III

\begin{tabular}{|c|c|c|c|c|}
\hline ALI WOMEN & $\mathbf{N}$ & $\begin{array}{l}\text { Divorce } \\
\text { Rate }\end{array}$ & $\begin{array}{l}\text { Divorce Rate } \\
\text { Adjusted for } \\
\text { Independent } \\
\text { Variables }\end{array}$ & $\begin{array}{l}\text { Divorced Rate } \\
\text { Adjusted for } \\
\text { Independent } \\
\text { Variables + } \\
\text { Corvariates }\end{array}$ \\
\hline $\begin{array}{l}\text { WOMEN WITH INSUFFICIENT } \\
\text { INCOME, } 1970\end{array}$ & 1437 & .01 & & \\
\hline $\begin{array}{c}\text { own Income } \\
1970 \\
0 \\
1-1000 \\
1001-2000 \\
2001-3000 \\
3001-4000 \\
4001-5000 \\
\text { BEIA }\end{array}$ & $\begin{array}{r}876 \\
241 \\
171 \\
111 \\
49 \\
9\end{array}$ & $\begin{array}{l}.01 \\
.01 \\
.00 \\
.01 \\
.06 \\
.22 \\
.16\end{array}$ & $\begin{array}{l}.01 \\
.01 \\
.00 \\
.00 \\
.04 \\
.19 \\
.13\end{array}$ & $\begin{array}{l}.01 \\
.01 \\
.00 \\
.01 \\
.04 \\
.19 \\
.13\end{array}$ \\
\hline $\begin{array}{l}\text { Husband-Wife } \\
\text { Income Ratio } \\
1970 \\
0-80 \\
81-\mathrm{HI} \\
\text { BETA }\end{array}$ & $\begin{array}{r}1406 \\
31\end{array}$ & $\begin{array}{l}.01 \\
.06 \\
.12\end{array}$ & $\begin{array}{l}.01 \\
.05 \\
.08\end{array}$ & $\begin{array}{l}.01 \\
.04 \\
.06\end{array}$ \\
\hline $\begin{array}{l}\text { WOMEN WITH SUFFICIENT } \\
\text { INCOME, } 1970\end{array}$ & 486 & .03 & & \\
\hline $\begin{array}{c}\text { Own Income } \\
1970 \\
2001-3000 \\
3001 \text { - } 4000 \\
4001 \text { - } 5000 \\
5001 \text { - } 6000 \\
6001 \text { - } 7000 \\
7001=8000 \\
8001=9000 \\
9001=\mathrm{HI} \\
\text { BETA }\end{array}$ & $\begin{array}{r}34 \\
93 \\
113 \\
93 \\
57 \\
47 \\
21 \\
28\end{array}$ & $\begin{array}{l}.03 \\
.05 \\
.02 \\
.01 \\
.02 \\
.07 \\
.05 \\
.00 \\
.11\end{array}$ & $\begin{array}{l}.04 \\
.06 \\
.03 \\
.02 \\
.02 \\
.06 \\
.04 \\
.00 \\
.12\end{array}$ & $\begin{array}{l}.04 \\
.06 \\
.02 \\
.02 \\
.02 \\
.06 \\
.06 \\
.00 \\
.11\end{array}$ \\
\hline $\begin{array}{l}\text { Husband-Wife } \\
\text { Income Ratio } \\
1970 \\
0-80 \\
81-\text { HI } \\
\text { BETA }\end{array}$ & $\begin{array}{l}334 \\
152\end{array}$ & $\begin{array}{l}.02 \\
.06 \\
.13\end{array}$ & $\begin{array}{l}.02 \\
.06 \\
.14\end{array}$ & $\begin{array}{l}.02 \\
.06 \\
.14\end{array}$ \\
\hline
\end{tabular}




\section{CHAPTER 4}

\section{CONCLUSIONS}

This analysis of the impact of women's labor force participation on marital dissolution supported the hypothesis that wives who are capable of self-support are more likely to divorce: women with sufficient incomes were three times more likely to divorce than women with insufficient incomes. Examination of the divorce rate for each income level among women with the two groups (women with sufficient and women with insufficient incomes) further demonstrated the importance of women's economic self-sufficiency in determining divorce. The divorce rate increased as women's income approached sufficiency, but once that point was passed the impact of income on divorce diminished. These results support the contention that women's labor force participation affects marital stability primarily insofar as wives are able to achieve economic independence.

It was hypothesized that divorce would be lower among couples with more equal incomes, because these marriages are more likely to be egalitarian and, therefore, more satisfying to women. This hypothesis was disconfirmed. The data showed a positive rather than a negative association between relatively equal husband-wife income ratios and divorce. 
This result appears to contradict previous research demonstrating greater satisfaction among husbands and wives in "parallel" marriages. A possible explanation for this result has been advanced. While closer husband-wife incomes may result in "parallel" marriages for those couples who remain married, similar incomes may also result in higher conflict and higher divorce rates, as wives make more demands which husbands are unwilling to meet. In this case, husbands rather than wives may initiate the divorce--especially in those instances where women are not economically self-sufficient. Since the survey did not include information necessary to test this explanation, further exploration has to be deferred.

In addition to revealing an interesting direction for research on the impact of women's labor force participation on marital stability, this study indicates that increasing economic opportunity for women has contributed to the rising divorce rate. As more wives become permanently employed in better paying jobs, divorce can be expected to remain high. Analysis of the younger women cohort in the NLS survey-those women who were 14-24 when the survey began in 1968-and comparison with the older women studied in this research should be an interesting area for further exploring the relationship between women's labor force participation, women's economic independence, and divorce. 


\section{BIBLIOGRAPHY}

Amsden, Alice $\mathrm{H}$.

1980 The Economics of Women and Work. New York: St. Martin's Press.

Benston, Margaret

1969 "The Political Economy of Women's Liberation," Monthly Review. (September), pp. 13-27.

Blau, Francine D.

1978 "The Data on Women Workers: Past, Present and Future." Women Working, ed. Stromberg A. and Harkess S. California: Mayfield Publishing Company, p. 43 .

Blumstein, Philip and Schwartz, Pepper.

1983 American Couples: Money, Work, Sex. New York:

Cherlin, Andrew $\mathrm{J}$.

1981 Marriage, Divorce, Remarriage. England: Harvard University Press.

Duncan, Greg J. and Morgan, James N.

1976 Five Thousand American Families = Patterns of Economic Program. Michigan: Institute for Social Research.

Grimm, James W.

1978

"Women in Female-Dominated Profession," Women Working, ed. Stromberg A. and Harkess S. California: Mayfield Publishing Company, p. 294 .

Groeneveld L.P., Tuma N.B., and Hannan M.T. 1980

"The Effect of Negative Income Tax Programs on Marital Dissolution," Journal of Human Resources, 15 (1980) pp. 654-74.

Hampton, Robert

1979 "Husbands Characteristics and Marital Disruption in Black Families." Sociological Quarterly, 20 (Spring), pp. 255-266. 
Hampton, Robert

1976 "Marital Disruption: Some Social and Economic Consequences." 5000 American Families.

Michigan: Institute for Social Research, vol. II I, Ch. 4 .

Huber, Joan and Glenna Spitze.

1983 Sex Stratification: Children, Housework, and Jobs. New York: Academic Press Inc.

Lloyd, Cynthia B.

1975 Sex Discrimination and Division of Labor. New York and London: Columbia University Press.

Moore, K.A. and Sawhill, I.V.

1978 "Implications of Women's Employment for Home and Family Life." Work and Family. ed. Voydanoff, P. Mayfield Publishing Company.

Mott, L. Frank.

1982 The Employment Revolution: Young American Women of the 1970's. Cambridge, Mass: MIT Press.

Mott, L. Frank and Moore, F. Sylvia.

1979 "The Causes of Marital Disruption Among Young American Women: An Interdisciplinary

Perspective." Journal of Marriage and Family, 41, pp. 355-365.

Moynihan, Daniel P.

1967 "The Negro Family: The Case for National

Action." The Moynihan Report and the Politics of Controversy. eds. Rainwater, L. and Yancey, L.Y. Cambridge, Mass: M.I.T. Press. pp. 39124 .

Norton, A.J. and Glick, P.C.

1976 "Marital Instability: Past, Present and Future." Journal of Social Issues. 32 , no. 1 , pp. 5-19.

Nye, Ivan and Hoffman, Wladis Lois.

1963 The Employed Mother in America. Chicago: Rand MCNally Company.

Oppenheimer, Valerie.

1979 "Structural Sources for Wives to Work: An Analytical Framework." Journal of Family History. 4,2, Summer, pp. 177-197,

Oppenheimer, Valerie.

1969 The Female Labor $\frac{\text { Force }}{\text { California, }}$ institue $\frac{\text { United }}{\text { tute }} \frac{\text { States }}{\text { International Studies. }}$ 
Rosenfeld, Jeffrey P.

1982 Relationships: $\frac{\text { The Marriage }}{\text { Illinois: Scott, }} \frac{\text { and }}{\text { Family }} \frac{\text { Reader. }}{\text { Fesman and Company. }}$

Ross, E. Catherine, Mirowsky, John, and Huber, Joan.

1983 "Dividing Work, Sharing Work, and Inbetween:

Marriage Patterns and Depression." American

Sociological Review, vol. 48 December, pp. 809-823.

Rothman, Robert A.

1978 Inequality and Stratification in the United

States. New Jersey: Prentice Hall Inc.

Sawhill, Isabell V.

1980 "Economic Perspectives on the Family." The Economics of Women and Work. New York: $\overline{\mathrm{St}}$. Martin's press.

Scanzoni, John.

1978 Sex Roles, Women's $\frac{\text { Work, }}{\text { Lexington, }} \frac{\text { and }}{\text { Mass.: }} \frac{\text { Marital }}{\text { Lexingtonflict. }}$

Semyonov, Moshe.

1980 "The Social Context of Women's Labor Force

Participation: A Comparative Analysis." AJS,

86,3 , Nov., pp. 534-550.

Shaw, Lois Banfill.

1983 The Working Lives $\frac{\text { of }}{\text { Lexington, Mass: }} \frac{\text { Middle-Aged Women. }}{\text { Health. }}$

Slesinger, Doris P.

1980 "Rapid Changes in Household Composition Among

Low Income Mothers." Family Relations, 29, 2, April, pp. 221-228.

Statistical Abstract

1984 United States. Washington, D.C.: Government Printing office, p. 447 .

Stromberg, Ann H. and Harkess, Shirley.

1978 Women Working. California: Mayfield Publishing Company.

U.S. Bureau of the Census.

1980 Washington D.C.: U.S. Government Printing Office.

Vanek, Joann

1974 "Time Spent in Housework." Scientific

American, vol. 231 (November), pp. 116-120. 
Voydanoff, Patricia.

1984 Work and Family. California: Mayfield Publishing Company.

Wispisinger, William W.

1984 "Rebuilding America with Full Employment." , Socialist Review. Numbers 75-76, vol. 14 (May, August) pp. 16-24.

Zaretsky, Eli

1976 Capitalism, The Family, and Personal Life, New York: Harper \& ROW, Publishers, Inc. 